\title{
AGRONOMIC PERFORMANCE OF COWPEA ELITE LINES IN THE STATES OF MINAS GERAIS AND MATO GROSSO, BRAZIL ${ }^{1}$
}

\author{
VANET BATISTA DE SOUZA², ABNER JOSÉ DE CARVALHO ${ }^{3}$, KAESEL JACKSON DAMASCENO-SILVA4, \\ MAURISRAEL DE MOURA ROCHA ${ }^{4}$, MARLON LOPES LACERDA ${ }^{3}$, ISRAEL ALEXANDRE PEREIRA FILHO ${ }^{5}$
}

\begin{abstract}
The objective of this work was to evaluate the agronomic performance of erect and semi-erect cowpea elite lines grown in the States of Minas Gerais and Mato Grosso, Brazil. The experiments were conducted in Jaíba, Janaúba, Sete Lagoas (Minas Gerais), Primavera do Leste and Nova Ubiratã (Mato Grosso), with 20 genotypes of cowpea, arranged in a randomized block design with four replications. The data were subjected to individual and joint analyses of variance and means grouped by the Scott-Knott test $(p<0.05)$. The plant growth habit, lodging, cultivation value, pod length and bean yield were evaluated. The lines MNC04768F-21 and MNC04F-795F-168 had the highest bean yield in the experiments conducted in Mato Grosso, and their growth habit, lodging and cultivation value were similar to those of the cultivar BRS-Guariba. The lines MNC04-769F-30, MNC05-795F-154 and MNC04-769F-49 and the cultivar BRS-Tumucumaque had the highest bean yield in the experiments conducted in Minas Gerais. However, the cultivars BRS-Guariba, BRSTumucumaque, BRS-Novaera, BRS-Itaim and BRS-Cauamé and the lines MNC04-792F-143 and MNC04792F-144 showed satisfactory bean yield and good growth habit, plant lodging and cultivation value in the State of Minas Gerais, especially in the northern region of the state (Jaíba and Janaúba), representing good alternatives for the genotypes recommended for this region.
\end{abstract}

Keywords: Vigna unguiculata L.. Yield. Cultivation value. Genotype-environment interaction.

\section{DESEMPENHO DE LINHAGENS ELITE DE FEIJÃO-CAUPI EM AMBIENTES DE MINAS GERAIS E MATO GROSSO}

RESUMO - O objetivo do trabalho foi avaliar o desempenho de linhagens elite de feijão-caupi de porte ereto e semiereto em ambientes de Mato Grosso e Minas Gerais. Os ensaios foram conduzidos em Jaíba, Janaúba e Sete Lagoas em Minas Gerais, e em Primavera do Leste e Nova Ubiratã em Mato Grosso. Foram avaliados 20 genótipos de feijão-caupi. Utilizou-se o delineamento de blocos casualizados, com quatro repetições. Os dados obtidos foram submetidos a análises de variância individuais e conjunta e as médias agrupadas pelo teste de Scott-Knott $(\mathrm{P}<0,05)$. Foram avaliados os caracteres porte da planta, acamamento, valor de cultivo, comprimento de vagem e rendimento de grãos. Nos ambientes do Mato Grosso, destacaram-se as linhagens MNC04-768F-21 e MNC04F-795F-168 como as mais produtivas e com características de porte da planta, acamamento e valor de cultivo semelhantes às da cultivar BRS Guariba. Nos ambientes de Minas Gerais, especialmente na região Norte do Estado, representada pelos ambientes de Jaíba e Janaúba, destacaram-se como mais produtivas as linhagens MNC04-769F-30, MNC05-795F-154, MNC04-769F-49 e a cultivar BRS Tumucumaque. Entretanto, as cultivares BRS Guariba, BRS Tumucumaque, BRS Novaera, BRS Itaim e BRS Cauamé, e as linhagens MNC04-792F-143 e MNC04-792F-144 apresentam produtividades satisfatórias e boas características de porte, acamamento e valor de cultivo, representando boas alternativas para recomendação de cultivo nesta região.

Palavras-chave: Vigna unguiculata L.. Produtividade. Valor de cultivo e uso. Interação genótipos x ambientes.

\footnotetext{
${ }^{*}$ Corresponding author

${ }^{1}$ Received for publication in 09/01/2016; accepted in 04/11/2017.

Paper approved from IV CONAC 2016.

Paper extracted from the Master dissertation of the first author.

${ }^{2}$ Department of Agronomy, Universidade Estadual de Maringá, Maringá, PR, Brazil; vanetbatista@yahoo.com.br.

${ }^{3}$ Department of Agrarian Sciences, Universidade Estadual de Montes Claros, Janaúba, MG, Brazil; abjocar@yahoo.com.br, marlon.lopesagronomia@gmail.com.

${ }^{4}$ Embrapa Meio-Norte, Teresina, PI, Brazil; kaesel.damasceno@embrapa.br, maurisrael.rocha@embrapa.br.

${ }^{5}$ Embrapa Milho e Sorgo, Sete Lagoas, MG, Brazil; israel.pereira@embrapa.br.
} 


\section{INTRODUCTION}

The world planted area of cowpea is 10.4 million hectares, which is located mainly in tropical and subtropical regions of America, Asia and Africa; the world production of cowpea beans is about 5.5 million $\mathrm{Mg}$, and Nigeria is the world's largest producer (FAO, 2016).

Cowpea is mainly grown in Brazil by small farms using low technological level, thus, the average national crop yield is very low, approximately $401 \mathrm{~kg} \mathrm{ha}^{-1}$ (EMBRAPA, 2016). However, the demand for cultivars with appropriate characteristics to planting and harvesting mechanization is increasing due to the interest of more producers in this crop (FREIRE FILHO, 2011). Thus, researches have sought to develop genotypes of more erect growth habit, compact architecture and more adapted to mechanization, that result in shorter maturation cycle, greater plant densities and higher yields.

The Northeast of Brazil is the main producing region of cowpea, however, its production area has expanded to the Brazilian Southeast and Center-West regions, especially to the State of Mato Grosso, where it is produced on approximately 140,000 hectares (CONAB, 2016), focused mainly in international markets. Cowpea crops are conducted with high technology in these new areas, with pest and disease control, balanced soil fertilization and mechanized harvesting. The northern State of Minas Gerais (Brazilian Southeast region) has an expressive consumer market and production of cowpea, however, this production is limited by several factors, especially by the low technology level used and current cultivars recommended for planting in this region, which are based on results of researches carried out in other regions of the country.

In this context, the objective of this work was to evaluate the agronomic performance of erect and semi-erect cowpea elite lines in the States of Minas Gerais and Mato Grosso, Brazil.

\section{MATERIAL AND METHODS}

The experiments were conducted in Jaíba, Janaúba and Sete Lagoas in the State of Minas Gerais (MG) and in Primavera do Leste and Nova Ubiratã, in the State of Mato Grosso (MT), in 2013 (Jaíba, Primavera do Leste and Nova Ubiratã) and 2014 (Janaúba and Sete Lagoas) during the summer-fall crop season, with planting in February to March.

These locations are considerable different in edaphoclimatic conditions; they include the Cerrado, Cerrado-Amazon and Cerrado-Caatinga biomes.

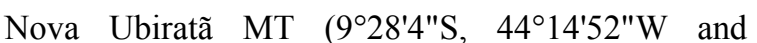
altitude of $400 \mathrm{~m}$ ), located in a Cerrado-Amazon transition ecosystem, has annual average temperature of $26.3{ }^{\circ} \mathrm{C}$, annual average rainfall of $2.250 \mathrm{~mm}$ and predominance of Yellow Latosol (Oxisol). Primavera do Leste $\left(15^{\circ} 33^{\prime} 32^{\prime \prime} \mathrm{S}, 5^{\circ} 17^{\prime} 46^{\prime \prime} \mathrm{W}\right.$ and altitude of $465 \mathrm{~m}$ ), located in an ecosystem with characteristics of Cerrado, has annual average temperature of $23.7^{\circ} \mathrm{C}$, annual average precipitation of $1,784 \mathrm{~mm}$ and predominance of Yellow Latosol (Oxisol) (IBGE, 2016).

Jaíba $\left(15^{\circ} 20^{\prime} 18^{\prime \prime} \mathrm{S}, 43^{\circ} 40^{\prime} 18^{\prime \prime} \mathrm{W}\right.$ and altitude

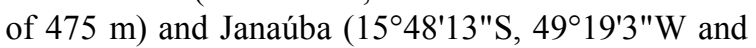
altitude of $510 \mathrm{~m}$ ) are located in the northern region of Minas Gerais, whose predominant ecosystem is Cerrado-Caatinga. They have semiarid climate, annual average precipitation of $900 \mathrm{~mm}$, annual average temperature of $24{ }^{\circ} \mathrm{C}$ and predominance of

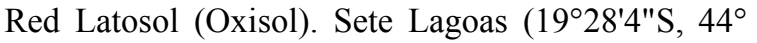
$14^{\prime} 52^{\prime \prime} \mathrm{W}$ and altitude of $751 \mathrm{~m}$ ), located in a Cerrado ecosystem, has humid tropical climate, annual average temperature of $19{ }^{\circ} \mathrm{C}$, annual average precipitation of $1,384 \mathrm{~mm}$ and predominance of Yellow Latosol (Oxisol) (IBGE, 2016).

The experiments were conducted with 20 erect and semi-erect cowpea genotypes, consisted of 15 elite lines and five cultivars (controls). These genotypes were selected by the Cowpea Breeding Program of the Embrapa Meio-Norte and subjected to cultivation and use value experiments in 2013 to 2014 (Table 1).

A randomized block experimental design with four replications was used, with plots consisted of four 5-meter rows, spaced $0.50 \mathrm{~m}$ apart, totaling an area of $10 \mathrm{~m}^{2}$, and evaluation area of $5 \mathrm{~m}^{2}$ (two central rows).

Conventional system of soil preparation was used in all locations evaluated, with one plowing and two harrowings at pre-planting. The soils of the areas were then furrowed and fertilized with a fertilizer equipment with spacing and rates adjusted as required. Sowing was carried out with manual seeders. The recommendations of Melo, Cardoso and Salviano (2005) for fertilization of cowpea crops was followed.

Approximately 15 seeds per meter were sown and after their germination a thinning was carried out, leaving approximately ten plants per meter. Manual weeding with hoes was performed from the $20^{\text {th }}$ to the $30^{\text {th }}$ day after emergence.

Irrigation was performed by a conventional sprinkler system from planting to the beginning of maturation in Jaíba, Janaúba and Sete Lagoas. The experiment in Nova Ubiratã and Primavera do Leste were conducted in the rainfed system. Harvesting was carried out manually, according to the maturity of each genotype. 
Table 1. Erect and semi-erect cowpea genotypes subjected to cultivation and use value experiments in 2013 to 2014 and their parental and commercial subclass.

\begin{tabular}{ccc}
\hline Genotype & Parental & Commercial \\
Subclass
\end{tabular}

Plant growth habit, lodging, and cultivation value, which was visually attributed according to a scale of grades (Table 2), were evaluated at the physiological maturity stage. Pod length and bean yield were evaluated after harvesting. Twenty pods, randomly chosen in each plot, was measured during the harvesting to assess the mean pod length. The beans harvested in the evaluation area of each plot were weighed to estimate the bean yield, correcting their weights for beans with $13 \%$ of moisture and transforming their results to $\mathrm{kg} \mathrm{ha}^{-1}$.

Table 2. Scales of grades used to classify the growth habit, lodging and cultivation value of cowpea plants.

\begin{tabular}{|c|c|c|c|}
\hline Grade & Growth habit & Lodged plants (\%) & Cultivation value \\
\hline 1 & Erect & No lodged plant & $\begin{array}{l}\text { Line/cultivar without suitable characteristics for } \\
\text { commercial cultivation }\end{array}$ \\
\hline 2 & Semi-erect & 1 to 5 & $\begin{array}{l}\text { Line/cultivar with little suitable characteristics for } \\
\text { commercial cultivation }\end{array}$ \\
\hline 3 & Semi-prostrate & 6 to 10 & $\begin{array}{l}\text { Line/cultivar with most of the suitable characteristics for } \\
\text { commercial cultivation }\end{array}$ \\
\hline 4 & Prostrate & 11 to 20 & $\begin{array}{c}\text { Line/cultivar with all suitable characteristics for } \\
\text { commercial cultivation }\end{array}$ \\
\hline 5 & - & Above of 20 & $\begin{array}{l}\text { Line/cultivar with all excellent characteristics for } \\
\text { commercial cultivation }\end{array}$ \\
\hline
\end{tabular}

The data were subjected to individual and joint analyzes of variance. The homogeneity of the residual variances was evaluated for the joint analysis. It was found that the ratio between the highest and The mean square of the residue was greater than Seven, indicating that the residual variances were homogeneous (PIMENTEL-GOMES, 2009). Like this, adjustment of the degrees of freedom of the Mean and GxE interaction, according to the method of Cochran (1954).

The relevance of each source of variation in the total variation of the mean was estimated by the ratio between the sum of squares of the source of variation $i\left(\mathrm{SQ}_{\mathrm{i}}\right)$ and the total sum of squares $\left(\mathrm{SQ}_{\mathrm{t}}\right)$, thus defining the coefficient of determination $\left(\mathrm{R}^{2}\right)$. The means of the genotype were grouped by the Scott-Knott test $(p<0.05)$. All analyses were performed using the program GENES (CRUZ, 2006).

\section{RESULTS AND DISCUSSION}

The analysis of variance showed a significant effect of the genotype (G) and environment (E) on all characteristics evaluated. The genotype $\mathrm{x}$ environment interaction (GxE) affected most of the characteristics evaluated, except pod length (Table 3).

According to the coefficient of determination $\left(\mathrm{R}^{2}\right)$ found, the effect of the genotypes was responsible for most of the total variation of the pod length means. The environment as a source of variation was the main responsible for the variation of the growth habit and bean yield means in Janaúba, Jaíba, Sete Lagoas, Nova Ubiratã and Primavera do Leste, and the GxE caused the greatest variation in the means of plant lodging and cultivation value of the genotypes evaluated (Table 3). 
Table 3. Joint analysis of variance of growth habit, lodging, cultivation value, pod length and bean yield of 20 erect and semi-erect cowpea genotypes, evaluated in five environments of the States of Minas Gerais and Mato Grosso, Brazil.

\begin{tabular}{|c|c|c|c|c|c|c|c|c|c|c|c|}
\hline \multirow{3}{*}{$\begin{array}{l}\text { Source of } \\
\text { Variation }\end{array}$} & \multirow{3}{*}{ DF } & \multicolumn{2}{|c|}{ Growth habit } & \multicolumn{2}{|c|}{ Lodging } & \multicolumn{2}{|c|}{ Cultivation value } & \multicolumn{2}{|c|}{ Pod length } & \multicolumn{2}{|c|}{ Bean yield } \\
\hline & & MS & $\mathrm{R}^{2}$ & MS & $\mathrm{R}^{2}$ & MS & $\mathrm{R}^{2}$ & MS & $\mathrm{R}^{2}$ & MS & $\mathrm{R}^{2}$ \\
\hline & & & $(\%)$ & & $(\%)$ & & $(\%)$ & $(\mathrm{cm})$ & (\%) & $\left(\mathrm{kg} \mathrm{ha}^{-1}\right)$ & $(\%)$ \\
\hline Blocks & & $0.11^{\mathrm{ns}}$ & & $0.33^{\mathrm{ns}}$ & & $0.59^{\text {ns }}$ & & $0.49^{\text {ns }}$ & & $412832.032^{\mathrm{ns}}$ & \\
\hline Genotype (G) & 19 & $0.19^{*}$ & 7.4 & $5.67 *$ & 23.29 & $2.22 *$ & 15.62 & $37.23^{*}$ & 40.14 & $412832.03 *$ & 9.22 \\
\hline Environment (A) & 4 & $5.53 *$ & 44.07 & $24.94 *$ & 21.59 & $6.63 *$ & 9.8 & $16.17 *$ & 3.58 & $8406950.79 *$ & 38.68 \\
\hline $\mathrm{GxE}$ & 76 & $0.10^{*}$ & 32.41 & $2.22 *$ & 36.51 & $1.12 *$ & 42.54 & $1.47^{\mathrm{ns}}$ & 5.85 & $364929.39 *$ & 31.90 \\
\hline Residue & 285 & 0.05 & & 0.28 & & 0.37 & & 1.77 & & 58376.31 & \\
\hline $\mathrm{CV} \%$ & & 15.09 & & 21.42 & & 23.76 & & 19.18 & & 16.3 & \\
\hline
\end{tabular}

$*=$ significant at $5 \%$ and ${ }^{\mathrm{ns}}=$ not significant by the $\mathrm{F}$ test. $\mathrm{R}^{2}=$ Coefficient of determination $(\%)$; $\mathrm{CV}=$ coefficient of variation (\%); $\mathrm{DF}=$ degrees of freedom; $\mathrm{MS}=$ mean square.

According to the results of the coefficient of determination, the pod length was greatly affected by the genotype and little affected by the environment. This result is due to the high heritability of the pod length, which is an important and desirable characteristic for the selection of lines (TEIXEIRA et al., 2007).

Bean yield was significantly affected by $\mathrm{G}, \mathrm{E}$ and G-E, which were responsible for $38.68 \%$ (E), $31.90 \%$ (G-E) and $9.22 \%$ (E) of its variations (Table $3)$. These results were probably because the genetic similarity between the genotypes, since most of them have common parents (Table 1). Moreover, bean yield is a polygenic quantitative characteristic, and thus highly affected by the environment (SANTOS et al., 2014).

The lines MNC04-769F-49, MNC04-792F144, MNC04-792F-148, MNC04-795F-153, MNC04 $-795 \mathrm{~F}-155$ and MNC04-795F-168 and the cultivars
BRS-Guariba, BRS, Tumucumaque, BRS-Novaera and BRS-Itaim were the most erect genotypes in Jaíba, with maximum growth habit of 1.43 . The genotypes showed similarity for growth habit in Janaúba and Sete Lagoas. The cultivar BRS-Itaim was more erect than the other genotypes Nova Ubiratã and Primavera do Leste, and the only one among the more erect genotypes in all environments. MNC04-769F-49, MNC04-792F-144, MNC04-792F-148, MNC04-795F-153, MNC04795F-155, MNC04-795F-168, BRS-Guariba, BRSTumucumaque and BRS-Novaera were among the most erect genotypes in the environments of Minas Gerais (Table 4).

Growth habit is an important characteristic and its improvement is one of the main objectives of cowpea breeding researches, since it selects more adapted cultivars to mechanization, which has been adopted by producers.

Table 4. Average grades attributed to growth habit of 20 genotypes of cowpea, evaluated in five environments of the States of Minas Gerais and Mato Grosso, Brazil.

\begin{tabular}{cccccc}
\hline \multirow{2}{*}{ Genotype } & \multicolumn{5}{c}{ Environment } \\
\cline { 2 - 6 } & Jaíba & Janaúba & Sete Lagoas & $\begin{array}{c}\text { Nova } \\
\text { Ubiratã }\end{array}$ & $\begin{array}{c}\text { Primavera } \\
\text { do Leste }\end{array}$ \\
\hline MNC04-762F-3 & $1.43 \mathrm{Ba}$ & $1.50 \mathrm{Aa}$ & $1.25 \mathrm{Aa}$ & $2.00 \mathrm{Bb}$ & $2.00 \mathrm{Bb}$ \\
MNC04-768F-21 & $1.62 \mathrm{Bb}$ & $1.37 \mathrm{Aa}$ & $1.25 \mathrm{Aa}$ & $1.62 \mathrm{Bb}$ & $1.75 \mathrm{Bb}$ \\
MNC04-769F-30 & $1.50 \mathrm{Ba}$ & $1.31 \mathrm{Aa}$ & $1.50 \mathrm{Aa}$ & $2.00 \mathrm{Bb}$ & $1.62 \mathrm{Ba}$ \\
MNC04-769F-48 & $1.62 \mathrm{Bb}$ & $1.31 \mathrm{Aa}$ & $1.31 \mathrm{Aa}$ & $1.75 \mathrm{Bb}$ & $1.87 \mathrm{Bb}$ \\
MNC04-769F-49 & $1.25 \mathrm{Aa}$ & $1.31 \mathrm{Aa}$ & $1.37 \mathrm{Aa}$ & $1.75 \mathrm{Bb}$ & $1.75 \mathrm{Bb}$ \\
MNC04-769F-62 & $1.50 \mathrm{Ba}$ & $1.37 \mathrm{Aa}$ & $1.25 \mathrm{Aa}$ & $1.87 \mathrm{Bb}$ & $1.87 \mathrm{Bb}$ \\
MNC04-782F-104 & $1.62 \mathrm{Bb}$ & $1.37 \mathrm{Aa}$ & $1.25 \mathrm{Aa}$ & $1.87 \mathrm{Bb}$ & $1.75 \mathrm{Ba}$ \\
MNC04-792F-143 & $1.68 \mathrm{Bb}$ & $1.25 \mathrm{Aa}$ & $1.50 \mathrm{Aa}$ & $2.00 \mathrm{Bb}$ & $1.75 \mathrm{Bb}$ \\
MNC04-792F-144 & $1.12 \mathrm{Aa}$ & $1.43 \mathrm{Aa}$ & $1.31 \mathrm{Aa}$ & $1.75 \mathrm{Bb}$ & $1.75 \mathrm{Bb}$ \\
MNC04-792F-148 & $1.31 \mathrm{Aa}$ & $1.43 \mathrm{Aa}$ & $1.37 \mathrm{Aa}$ & $2.00 \mathrm{Bb}$ & $2.00 \mathrm{Bb}$ \\
MNC04-795F-153 & $1.31 \mathrm{Aa}$ & $1.37 \mathrm{Aa}$ & $1.25 \mathrm{Aa}$ & $2.00 \mathrm{Bb}$ & $2.00 \mathrm{Bb}$ \\
MNC04-795F-154 & $1.50 \mathrm{Ba}$ & $1.31 \mathrm{Aa}$ & $1.25 \mathrm{Aa}$ & $2.00 \mathrm{Bb}$ & $1.62 \mathrm{Ba}$ \\
MNC04-795F-155 & $1.31 \mathrm{Aa}$ & $1.31 \mathrm{Aa}$ & $1.50 \mathrm{Aa}$ & $2.00 \mathrm{Bb}$ & $2.00 \mathrm{Bb}$ \\
MNC04-795F-159 & $1.43 \mathrm{Ba}$ & $1.37 \mathrm{Aa}$ & $1.31 \mathrm{Aa}$ & $1.75 \mathrm{Bb}$ & $1.87 \mathrm{Bb}$ \\
MNC04-795F-168 & $1.31 \mathrm{Aa}$ & $1.43 \mathrm{Aa}$ & $1.37 \mathrm{Aa}$ & $2.00 \mathrm{Bb}$ & $1.75 \mathrm{Bb}$ \\
BRS-Guariba & $1.31 \mathrm{Aa}$ & $1.18 \mathrm{Aa}$ & $1.25 \mathrm{Aa}$ & $2.00 \mathrm{Bb}$ & $2.00 \mathrm{Bb}$ \\
BRS-Tumucumaque & $1.18 \mathrm{Aa}$ & $1.31 \mathrm{Aa}$ & $1.25 \mathrm{Aa}$ & $2.00 \mathrm{Bb}$ & $1.75 \mathrm{Bb}$ \\
BRS-Novaera & $1.31 \mathrm{Aa}$ & $1.18 \mathrm{Aa}$ & $1.50 \mathrm{Aa}$ & $2.00 \mathrm{Bb}$ & $2.00 \mathrm{Bb}$ \\
BRS-Itaim & $1.43 \mathrm{Ab}$ & $1.18 \mathrm{Ab}$ & $1.31 \mathrm{Ab}$ & $1.00 \mathrm{Aa}$ & $1.00 \mathrm{Aa}$ \\
BRS-Cauamé & $1.50 \mathrm{Ba}$ & $1.31 \mathrm{Aa}$ & $1.37 \mathrm{Aa}$ & $2.00 \mathrm{Bb}$ & $2.00 \mathrm{Bb}$ \\
\hline
\end{tabular}

Means followed by the same uppercase letter in the columns (comparing genotypes) and lowercase in the lines (comparing environments) do not differ by Scott-Knott test $(\mathrm{p}<0.05)$. 
Plant lodging was affected by the genotypes, except in Sete Lagoas. The mean test used grouped the genotypes according to grades attributed to the lodging. Thus, genotypes were grouped into four groups in Jaíba. The group with the lowest grades consisted of nine genotypes, with maximum grade of 1.25. The cultivars BRS-Novaera and BRS-Itaim, and the line MNC04-792F-143 had the lowest grade in Janaúba, with maximum grade of 1.50. Twelve genotypes with the lowest grades were grouped in Nova Ubiratã, with maximum grade of 1.25 , and 11 in Primavera do Leste, with maximum grade of 2.25 . The cultivars BRS-Novaera and BRS-Itaim were in the group of genotypes that had the lowest grades for plant lodging in all environments evaluated, denoting their greater resistance to lodging compared with the other genotypes evaluated (Table 5).

Rocha et al. (2011) evaluated the adaptability and stability of erect cowpea genotypes in the Brazilian Northeast region and found average plant lodging grade of 1.58 .

Table 5. Average grades attributed to plant lodging of 20 genotypes of cowpea, evaluated in five environments of the States of Minas Gerais and Mato Grosso, Brazil, from 2013 to 2014.

\begin{tabular}{cccccc}
\hline \multirow{2}{*}{ Genotype } & \multicolumn{3}{c}{ Environment } \\
\cline { 2 - 6 } & Jaíba & Janaúba & Sete Lagoas & $\begin{array}{c}\text { Nova } \\
\text { Ubiratã }\end{array}$ & $\begin{array}{c}\text { Primavera } \\
\text { do Leste }\end{array}$ \\
\hline MNC04-762F-3 & $2.50 \mathrm{Cc}$ & $3.50 \mathrm{Dd}$ & $3.25 \mathrm{Ad}$ & $1.00 \mathrm{Aa}$ & $2.00 \mathrm{Ab}$ \\
MNC04-768F-21 & $4.00 \mathrm{Db}$ & $3.75 \mathrm{Db}$ & $3.00 \mathrm{Aa}$ & $4.25 \mathrm{Db}$ & $2.75 \mathrm{Ba}$ \\
MNC04-769F-30 & $1.25 \mathrm{Aa}$ & $4.25 \mathrm{Dd}$ & $3.25 \mathrm{Ac}$ & $1.00 \mathrm{Aa}$ & $2.25 \mathrm{Ab}$ \\
MNC04-769F-48 & $3.75 \mathrm{Dc}$ & $3.00 \mathrm{Cb}$ & $3.75 \mathrm{Ac}$ & $1.25 \mathrm{Aa}$ & $2.50 \mathrm{Bb}$ \\
MNC04-769F-49 & $3.25 \mathrm{Ca}$ & $2.50 \mathrm{Ca}$ & $3.00 \mathrm{Aa}$ & $3.75 \mathrm{Da}$ & $3.00 \mathrm{Ba}$ \\
MNC04-769F-62 & $4.00 \mathrm{Dc}$ & $3.00 \mathrm{Cb}$ & $3.25 \mathrm{Ac}$ & $2.75 \mathrm{Cb}$ & $2.00 \mathrm{Aa}$ \\
MNC04-782F-104 & $4.00 \mathrm{Db}$ & $3.25 \mathrm{Ca}$ & $3.00 \mathrm{Aa}$ & $4.00 \mathrm{Db}$ & $2.50 \mathrm{Ba}$ \\
MNC04-792F-143 & $2.25 \mathrm{Bb}$ & $1.50 \mathrm{Aa}$ & $3.25 \mathrm{Ab}$ & $1.00 \mathrm{Aa}$ & $2.75 \mathrm{Bb}$ \\
MNC04-792F-144 & $1.00 \mathrm{Aa}$ & $3.50 \mathrm{Dc}$ & $3.75 \mathrm{Ac}$ & $3.25 \mathrm{Cc}$ & $2.50 \mathrm{Bb}$ \\
MNC04-792F-148 & $1.00 \mathrm{Aa}$ & $3.50 \mathrm{Dc}$ & $3.00 \mathrm{Ac}$ & $1.00 \mathrm{Aa}$ & $2.25 \mathrm{Ab}$ \\
MNC04-795F-153 & $2.00 \mathrm{Ba}$ & $4.00 \mathrm{Dc}$ & $3.25 \mathrm{Ac}$ & $2.00 \mathrm{Ba}$ & $2.75 \mathrm{Bb}$ \\
MNC04-795F-154 & $1.25 \mathrm{Aa}$ & $3.00 \mathrm{Cc}$ & $3.00 \mathrm{Ac}$ & $2.25 \mathrm{Bb}$ & $2.25 \mathrm{Ab}$ \\
MNC04-795F-155 & $1.25 \mathrm{Aa}$ & $2.75 \mathrm{Cb}$ & $3.25 \mathrm{Ab}$ & $1.00 \mathrm{Aa}$ & $2.75 \mathrm{Bb}$ \\
MNC04-795F-159 & $2.75 \mathrm{Ca}$ & $2.75 \mathrm{Ca}$ & $3.75 \mathrm{Ab}$ & $3.00 \mathrm{Ca}$ & $2.75 \mathrm{Ba}$ \\
MNC04-795F-168 & $1.00 \mathrm{Aa}$ & $3.25 \mathrm{Cb}$ & $3.00 \mathrm{Ab}$ & $1.00 \mathrm{Aa}$ & $1.50 \mathrm{Aa}$ \\
BRS-Guariba & $2.50 \mathrm{Cb}$ & $2.25 \mathrm{Bb}$ & $3.25 \mathrm{Ac}$ & $1.00 \mathrm{Aa}$ & $2.25 \mathrm{Ab}$ \\
BRS-Tumucumaque & $1.75 \mathrm{Ba}$ & $2.75 \mathrm{Cb}$ & $3.00 \mathrm{Ab}$ & $1.00 \mathrm{Aa}$ & $2.25 \mathrm{Ab}$ \\
BRS-Novaera & $1.00 \mathrm{Aa}$ & $1.41 \mathrm{Aa}$ & $3.25 \mathrm{Ac}$ & $1.00 \mathrm{Aa}$ & $2.00 \mathrm{Ab}$ \\
BRS-Itaim & $1.00 \mathrm{Aa}$ & $1.00 \mathrm{Aa}$ & $3.75 \mathrm{Ab}$ & $1.00 \mathrm{Aa}$ & $1.00 \mathrm{Aa}$ \\
BRS-Cauamé & $1.50 \mathrm{Aa}$ & $2.50 \mathrm{Cb}$ & $3.00 \mathrm{Ab}$ & $1.00 \mathrm{Aa}$ & $2.00 \mathrm{Ab}$ \\
\hline Mea & & & & \\
\hline
\end{tabular}

Means followed by the same uppercase letter in the columns (comparing genotypes) and lowercase in the lines (comparing environments) do not differ by Scott-Knott test $(\mathrm{p}<0.05)$.

According to Araújo and Watt (1988), low temperatures can prolong the vegetative phase of cowpea with emission of new branches, and a greater number of trifoliate leaves, favoring the lodging of cowpea plants. Sete Lagoas had the lowest average and minimum temperatures among the environments evaluated, and the highest grades for plant lodging (Table 5), denoting the lower resistance of the genotypes to lodging in this environment. This result denotes the effect of the environment on the growth habit of the lines and the need for recommendation of cultivars based on tests in different producing regions.

Genotypes with erect growth habit are selected for cultivars of low plant lodging and more compact and erect growth habit, which are suitable to grown in high technological fully-mechanized production systems. Thus, the lines
MNC04-792F-143 and MNC04-795F-155, and the cultivars BRS-Novaera and BRS-Itaim stood out with more erect growth habit and lower plant lodging in most of the environments evaluated.

The cultivation value represents the general aspects of the plant, such as architecture, pod loading, pod and bean quality and phytosanitary condition. Cultivation values of 3.0 is the minimum grade for commercial genotypes, indicating that the genotype has most of the suitable characteristics for commercial cultivation (Table 2). The cultivation values of the genotypes had significant differences in all environments evaluated (Table 6). According to the grouping test, the genotypes with the highest grades showed groups of 11 (Jaíba), 8 (Janaúba), 4 (Sete Lagoas), 6 (Nova Ubiratã) and 11 (Primavera do Leste) genotypes.

Thus, genotypes that stood out with good 
commercial characteristics were MNC04-792F-143, MNC04-792F-144 and BRS-Itaim in Jaíba; MNC04768F-21, MNC04-769F-49, MNC04-792F-143, MNC04-792F-144, BRS-Guariba, BRSTumucumaque, BRS-Novaera and BRS-Itaim in Janaúba; MNC04-768F-21, MNC04-769F-49, MNC04-792F-143, MNC04-792F-144, BRSGuariba, BRS-Tumucumaque, BRS-Novaera and BRS-Itaim in Sete Lagoas; MNC04-762F-3, MNC04 -795F-168, BRS-Guariba, BRS-Novaera, BRS-Itaim and BRS-Cauamé in Nova Ubiratã; and MNC04762F-3, MNC04-792F-144, MNC04-795F-168, BRS-Novaera and BRS-Itaim in Primavera do Leste, whose grades of cultivation value were higher than 3. The genotypes BRS-Novaera, BRS-Itaim and MNC04-795F-168 stood out as the only ones that presented grades equal to or above 3.0 in at least three of the five environments evaluated (Table 6). The line MNC04-795F-168 and the cultivar
BRS-Novaera produce beans classified in the commercial subclass Brancão (Table 1), which are large and rough beans, and preferred by many consumers in both domestic and international markets (FREIRE FILHO et al., 2008). According to Pereira et al. (2012), not only the bean yield is essential to select genotypes to develop new cultivars, but also other characteristics, such as growth habit, lodging and bean size.

The mean cultivation values found were higher than those found by Teixeira et al. (2007), who evaluated production and production components of erect cowpea genotypes in the Northeast region of Brazil and found average cultivation value of 2.59. Benvindo et al. (2010) evaluated the agronomic performance of irrigated and rainfed cowpea genotypes, also in the Northeast region of Brazil, and found average cultivation value of 3.7 .

Table 6. Average grades attributed to the cultivation value of 20 cowpea genotypes evaluated in five environments of the States of Minas Gerais and Mato Grosso, Brazil.

\begin{tabular}{cccccc}
\hline \multirow{2}{*}{ Genotype } & \multicolumn{3}{c}{ Environment } \\
\cline { 2 - 6 } & Jaíba & Janaúba & Sete Lagoas & $\begin{array}{c}\text { Nova } \\
\text { Ubiratã }\end{array}$ & $\begin{array}{c}\text { Primavera } \\
\text { do Leste }\end{array}$ \\
\hline MNC04-762F-3 & $1.75 \mathrm{Bb}$ & $2.50 \mathrm{Bb}$ & $2.50 \mathrm{Bb}$ & $3.75 \mathrm{Aa}$ & $3.25 \mathrm{Aa}$ \\
MNC04-768F-21 & $1.50 \mathrm{Bb}$ & $3.25 \mathrm{Aa}$ & $2.50 \mathrm{Ba}$ & $1.75 \mathrm{Bb}$ & $1.75 \mathrm{Bb}$ \\
MNC04-769F-30 & $2.25 \mathrm{Aa}$ & $2.00 \mathrm{Ba}$ & $3.00 \mathrm{Ba}$ & $2.00 \mathrm{Ba}$ & $2.00 \mathrm{Ba}$ \\
MNC04-769F-48 & $1.75 \mathrm{Ba}$ & $2.75 \mathrm{Ba}$ & $2.50 \mathrm{Ba}$ & $2.50 \mathrm{Ba}$ & $2.00 \mathrm{Ba}$ \\
MNC04-769F-49 & $1.50 \mathrm{Bb}$ & $3.00 \mathrm{Aa}$ & $3.75 \mathrm{Aa}$ & $2.00 \mathrm{Bb}$ & $1.75 \mathrm{Bb}$ \\
MNC04-769F-62 & $1.00 \mathrm{Bb}$ & $2.75 \mathrm{Ba}$ & $2.50 \mathrm{Ba}$ & $2.00 \mathrm{Ba}$ & $1.50 \mathrm{Bb}$ \\
MNC04-782F-104 & $1.75 \mathrm{Ba}$ & $2.25 \mathrm{Ba}$ & $2.50 \mathrm{Ba}$ & $2.00 \mathrm{Ba}$ & $2.25 \mathrm{Ba}$ \\
MNC04-792F-143 & $3.00 \mathrm{Aa}$ & $3.50 \mathrm{Aa}$ & $3.00 \mathrm{Ba}$ & $2.00 \mathrm{Bb}$ & $1.50 \mathrm{Bb}$ \\
MNC04-792F-144 & $3.25 \mathrm{Aa}$ & $3.25 \mathrm{Aa}$ & $2.75 \mathrm{Ba}$ & $2.00 \mathrm{Bb}$ & $3.00 \mathrm{Aa}$ \\
MNC04-792F-148 & $2.25 \mathrm{Ab}$ & $2.25 \mathrm{Bb}$ & $3.75 \mathrm{Aa}$ & $2.25 \mathrm{Bb}$ & $2.75 \mathrm{Ab}$ \\
MNC04-795F-153 & $2.75 \mathrm{Aa}$ & $2.25 \mathrm{Ba}$ & $2.50 \mathrm{Ba}$ & $2.00 \mathrm{Ba}$ & $2.50 \mathrm{Aa}$ \\
MNC04-795F-154 & $2.25 \mathrm{Aa}$ & $2.25 \mathrm{Ba}$ & $2.50 \mathrm{Ba}$ & $2.00 \mathrm{Ba}$ & $2.75 \mathrm{Aa}$ \\
MNC04-795F-155 & $2.25 \mathrm{Aa}$ & $2.75 \mathrm{Ba}$ & $3.00 \mathrm{Ba}$ & $2.50 \mathrm{Ba}$ & $2.25 \mathrm{Ba}$ \\
MNC04-795F-159 & $2.25 \mathrm{Aa}$ & $2.50 \mathrm{Ba}$ & $2.75 \mathrm{Ba}$ & $2.00 \mathrm{Ba}$ & $2.25 \mathrm{Ba}$ \\
MNC04-795F-168 & $1.75 \mathrm{Bb}$ & $2.25 \mathrm{Bb}$ & $3.75 \mathrm{Aa}$ & $3.75 \mathrm{Aa}$ & $3.25 \mathrm{Aa}$ \\
BRS-Guariba & $1.75 \mathrm{Bb}$ & $3.50 \mathrm{Aa}$ & $2.50 \mathrm{Bb}$ & $3.25 \mathrm{Aa}$ & $2.75 \mathrm{Aa}$ \\
BRS-Tumucumaque & $2.00 \mathrm{Ba}$ & $3.25 \mathrm{Aa}$ & $2.50 \mathrm{Ba}$ & $2.50 \mathrm{Ba}$ & $2.50 \mathrm{Aa}$ \\
BRS-Novaera & $2.50 \mathrm{Ab}$ & $3.00 \mathrm{Ab}$ & $3.00 \mathrm{Bb}$ & $4.00 \mathrm{Aa}$ & $3.00 \mathrm{Ab}$ \\
BRS-Itaim & $3.00 \mathrm{Aa}$ & $3.75 \mathrm{Aa}$ & $2.75 \mathrm{Ba}$ & $3.50 \mathrm{Aa}$ & $3.00 \mathrm{Aa}$ \\
BRS-Cauamé & $2.50 \mathrm{Ab}$ & $2.25 \mathrm{Bb}$ & $3.75 \mathrm{Aa}$ & $3.00 \mathrm{Ab}$ & $2.75 \mathrm{Ab}$ \\
\hline
\end{tabular}

Means followed by the same uppercase letter in the columns (comparing genotypes) and lowercase in the lines (comparing environments) do not differ by Scott-Knott test $(p<0.05)$.

The genotypes that stood out with the better results of pod length, according to the environment in which they were grown (Table 7) were MNC04-736F-30, MNC04-795F-168, BRS-Novaera and BRS-Itaim (Jaíba); MNC04-769F-49, MNC04769F-62, MNC04-795F-168, BRS Nova Era and BRS-Itaim (Janaúba); MNC04-769F-62, BRS Nova Era and BRS-Itaim (Sete Lagoas); MNC04-768F-21, MNC04-769F-30, MNC04-795F-159, MNC04-795F -168, BRS-Novaera and BRS-Itaim (Nova Ubiratã); and MNC04-768F-21, MNC04-736F-30, MNC04769F-48, MNC04-795F-168, BRS-Novaera and BRS-Itaim (Primavera do Leste). The cultivars BRSItaim and BRS-Novaera were superior in all environments and the line MNC04-795F-168 was among the genotypes with best results in Jaíba,
Janaúba, Nova Ubiratã and Primavera do Leste.

The ideal pod length for erect cowpea genotypes has not yet been established. However, Freire Filho (2011) reported average pod length of $18 \mathrm{~cm}$ for cultivars released between 1991 and 2010 . The pod length of the lines MNC04-795F-168, MNC04-769F-30, MNC04-769F-62 and MNC04$795 \mathrm{~F}-159$, and the cultivars BRS-Itaim, BRSNovaera and BRS-Guariba are within this range (Table 7). Smaller pods have been preferred by producers, since they facilitate harvest mechanization, and prevent contact of the pods with the soil and consequently, their rotting. Moreover, smaller pods are generally lighter and reduce bending and breaking of the peduncle at harvesting (SILVA; NEVES, 2011). 
Table 7. Average pod length $(\mathrm{cm})$ of 20 genotypes of cowpea, evaluated in five environments of the States of Minas Gerais and Mato Grosso from 2013 to 2014.

\begin{tabular}{cccccc}
\hline & \multicolumn{3}{c}{ Environment } \\
\cline { 2 - 6 } Genotype & Jaíba & Janaúba & Sete Lagoas & $\begin{array}{c}\text { Nova } \\
\text { Ubiratã }\end{array}$ & $\begin{array}{c}\text { Primavera } \\
\text { do Leste }\end{array}$ \\
\hline MNC04-762F-3 & $18.94 \mathrm{~B}$ & $19.71 \mathrm{~B}$ & $16.53 \mathrm{~B}$ & $20.15 \mathrm{~B}$ & $19.88 \mathrm{~B}$ \\
MNC04-768F-21 & $19.28 \mathrm{~B}$ & $19.32 \mathrm{~B}$ & $19.01 \mathrm{~B}$ & $18.95 \mathrm{~A}$ & $19.41 \mathrm{~A}$ \\
MNC04-769F-30 & $17.61 \mathrm{~A}$ & $16.66 \mathrm{~B}$ & $18.81 \mathrm{~B}$ & $18.50 \mathrm{~A}$ & $19.36 \mathrm{~A}$ \\
MNC04-769F-48 & $18.78 \mathrm{~B}$ & $18.63 \mathrm{~B}$ & $19.99 \mathrm{~B}$ & $20.90 \mathrm{~B}$ & $19.48 \mathrm{~A}$ \\
MNC04-769F-49 & $19.27 \mathrm{~B}$ & $18.38 \mathrm{~A}$ & $19.29 \mathrm{~B}$ & $19.55 \mathrm{~B}$ & $20.84 \mathrm{~B}$ \\
MNC04-769F-62 & $18.36 \mathrm{~B}$ & $18.14 \mathrm{~A}$ & $17.71 \mathrm{~A}$ & $17.80 \mathrm{~B}$ & $18.54 \mathrm{~A}$ \\
MNC04-782F-104 & $18.84 \mathrm{~B}$ & $18.74 \mathrm{~B}$ & $19.26 \mathrm{~B}$ & $19.90 \mathrm{~B}$ & $21.04 \mathrm{~B}$ \\
MNC04-792F-143 & $18.31 \mathrm{~B}$ & $18.64 \mathrm{~B}$ & $19.80 \mathrm{~B}$ & $20.11 \mathrm{~B}$ & $21.16 \mathrm{~B}$ \\
MNC04-792F-144 & $18.37 \mathrm{~B}$ & $20.18 \mathrm{~B}$ & $20.07 \mathrm{~B}$ & $20.11 \mathrm{~B}$ & $19.31 \mathrm{~A}$ \\
MNC04-792F-148 & $19.43 \mathrm{~B}$ & $19.32 \mathrm{~B}$ & $19.83 \mathrm{~B}$ & $19.90 \mathrm{~B}$ & $20.65 \mathrm{~B}$ \\
MNC04-795F-153 & $19.05 \mathrm{~B}$ & $19.74 \mathrm{~B}$ & $19.74 \mathrm{~B}$ & $20.05 \mathrm{~B}$ & $20.73 \mathrm{~B}$ \\
MNC04-795F-154 & $20.37 \mathrm{~B}$ & $19.97 \mathrm{~B}$ & $21.63 \mathrm{~B}$ & $21.75 \mathrm{~B}$ & $20.93 \mathrm{~B}$ \\
MNC04-795F-155 & $18.74 \mathrm{~B}$ & $19.85 \mathrm{~B}$ & $18.68 \mathrm{~B}$ & $20.10 \mathrm{~B}$ & $20.29 \mathrm{~B}$ \\
MNC04-795F-159 & $18.54 \mathrm{~B}$ & $19.56 \mathrm{~B}$ & $18.59 \mathrm{~B}$ & $18.65 \mathrm{~A}$ & $19.06 \mathrm{~A}$ \\
MNC04-795F-168 & $17.02 \mathrm{~A}$ & $16.93 \mathrm{~A}$ & $18.26 \mathrm{~B}$ & $16.20 \mathrm{~A}$ & $18.11 \mathrm{~A}$ \\
BRS-Guariba & $18.49 \mathrm{~B}$ & $18.12 \mathrm{~A}$ & $18.80 \mathrm{~B}$ & $18.30 \mathrm{~A}$ & $18.61 \mathrm{~A}$ \\
BRS-Tumucumaque & $20.30 \mathrm{~B}$ & $21.23 \mathrm{~B}$ & $21.83 \mathrm{~B}$ & $22.65 \mathrm{~B}$ & $21.93 \mathrm{~B}$ \\
BRS Nova Era & $16.22 \mathrm{~A}$ & $16.15 \mathrm{~A}$ & $15.04 \mathrm{~A}$ & $16.60 \mathrm{~A}$ & $16.91 \mathrm{~A}$ \\
BRS-Itaim & $15.99 \mathrm{~A}$ & $16.43 \mathrm{~A}$ & $15.79 \mathrm{~A}$ & $18.10 \mathrm{~A}$ & $17.38 \mathrm{~A}$ \\
BRS-Cauamé & $21.13 \mathrm{~B}$ & $21.13 \mathrm{~B}$ & $21.43 \mathrm{~B}$ & $21.57 \mathrm{~B}$ & $21.33 \mathrm{~B}$ \\
\hline
\end{tabular}

Means followed by the same uppercase letter in the columns (comparing genotypes) and lowercase in the lines (comparing environments) do not differ by Scott-Knott test $(p<0.05)$.

The bean yield varied in different environments with a same genotype (Table 8). According to Freire Filho et al. (2005), Rocha et al. (2007) and Matos Filho et al. (2009), differences in the same genotype in different environments can also occur as a function of biotic factors and genetic response to the environmental variations. Zilio et al. (2011) stated that these differences show the presence of genetic variability among the genotypes and the effect of the environment on them.

The most productive genotypes in Jaíba were BRS-Tumucumaque $\left(2,021.17 \mathrm{~kg} \mathrm{ha}^{-1}\right)$ and MNC04$795 \mathrm{~F}-154\left(1,730.27 \mathrm{~kg} \mathrm{ha}^{-1}\right)$.

The lines MNC04-769F-30 and MNC04$769 \mathrm{~F}-49$ had the highest bean yield in Janaúba, which had averages of $2,002.92$ to $2,590.47 \mathrm{~kg} \mathrm{ha}^{-1}$. The genotypes MNC04-769F-30, MNC04-769F-49, MNC04-792F-144, MNC04-795F-154, MNC04795F-155, MNC04-795F-159 and BRS-Novaera had the highest bean yield in Sete Lagoas, which had averages of $1,389.03$ to $1,730.78 \mathrm{~kg} \mathrm{ha}^{-1}$ (Table 8).

The genotypes MNC04-768F-21, MNC04795F-168, MNC04-762F-3, MNC04-795F-159 and BRS-Novaera had the highest bean yield in Nova Ubiratã, which had averages of 2,150.70 to 2,485.71 $\mathrm{kg} \mathrm{ha}^{-1}$. The lines MNC04-768F-21, MNC04-769F-
30, MNC04-792F-144, MNC04-795F-153, MNC04795F-168, and the cultivars BRS-Guariba, BRSTumucumaque, BRS-Novaera and BRS-Cauamé had the highest bean yield in Primavera do Leste, which had averages of $1,359.30$ to $1,823.22 \mathrm{~kg} \mathrm{ha}^{-1}$.

The genotypes MNC04-792F-144, MNC04782F-104, MNC04-769F-30, BRS-Guariba and BRS -Novaera had the highest bean yield in three of the five evaluated environments (Table 8). Nunes et al. (2014) also reported the cultivar BRS-Novaera as the most productive, in an experiment conducted in Primavera do Leste, with average bean yield of all genotypes evaluated of $2,103.53 \mathrm{~kg} \mathrm{ha}^{-1}$.

The bean yield found in this work can be considered high in most situations, since it was well above the national average of $401 \mathrm{~kg} \mathrm{ha}^{-1}$ (EMBRAPA, 2016). However, the national average often denotes the effect of the low technology applied to the crops, which affects bean yield. Moreover, a number of experiments (FREIRE FILHO et al., 2005; ROCHA et al., 2007; TEIXEIRA et al., 2010; VALADARES et al., 2012; BEZERRA et al., 2012; SANTOS et al., 2016) conducted in similar conditions, reported average yields between $1,015 \mathrm{~kg} \mathrm{ha}^{-1}$ and $1,390 \mathrm{~kg} \mathrm{ha}^{-1}$, which are close to those found in the present work. 
Table 8. Average bean yield $\left(\mathrm{kg} \mathrm{ha}^{-1}\right)$ of 20 erect and semi-erect cowpea genotypes evaluated in five environments of the States of Minas Gerais and Mato Grosso.

\begin{tabular}{crrrrr}
\hline & \multicolumn{3}{c}{ Environment } \\
\cline { 2 - 6 } Genotype & \multicolumn{1}{c}{ Jaíba } & Janaúba & Sete Lagoas & $\begin{array}{c}\text { Nova } \\
\text { Ubiratã }\end{array}$ & $\begin{array}{c}\text { Primavera } \\
\text { do Leste }\end{array}$ \\
\hline MNC04-762F-3 & $802.32 \mathrm{Dc}$ & $1,278.44 \mathrm{Cb}$ & $1,144.51 \mathrm{Bb}$ & $2,485.71 \mathrm{Aa}$ & $1,305.21 \mathrm{Bb}$ \\
MNC04-768F-21 & $1,19.56 \mathrm{Cc}$ & $1,653.25 \mathrm{Cb}$ & $1,108.25 \mathrm{Bc}$ & $2,331.49 \mathrm{Aa}$ & $1,659.74 \mathrm{Ab}$ \\
MNC04-769F-30 & $1,113.78 \mathrm{Cd}$ & $2,590.47 \mathrm{Aa}$ & $1,492.59 \mathrm{Ac}$ & $1,861.45 \mathrm{Bb}$ & $1,431.19 \mathrm{Ac}$ \\
MNC04-769F-48 & $936.83 \mathrm{Cb}$ & $1,570.31 \mathrm{Ca}$ & $975.66 \mathrm{Bb}$ & $1,883.50 \mathrm{Ba}$ & $1,166.55 \mathrm{Bb}$ \\
MNC04-769F-49 & $1,188.47 \mathrm{Cc}$ & $2,309.39 \mathrm{Aa}$ & $1,431.66 \mathrm{Ab}$ & $1,678.00 \mathrm{Bb}$ & $1,026.96 \mathrm{Bc}$ \\
MNC04-769F-62 & $1,370.48 \mathrm{Bc}$ & $1,610.90 \mathrm{Cb}$ & $1,236.16 \mathrm{Bc}$ & $1,978.20 \mathrm{Ba}$ & $1,267.28 \mathrm{Bc}$ \\
MNC04-782F-104 & $1,554.19 \mathrm{Bb}$ & $2,002.92 \mathrm{Ba}$ & $908.94 \mathrm{Bc}$ & $2,013.10 \mathrm{Ba}$ & $973.35 \mathrm{Bc}$ \\
MNC04-792F-143 & $1,243.11 \mathrm{Cb}$ & $1,889.33 \mathrm{Ba}$ & $1,149.06 \mathrm{Bb}$ & $2,080.60 \mathrm{Ba}$ & $1,080.24 \mathrm{Bb}$ \\
MNC04-792F-144 & $1,228.76 \mathrm{Cb}$ & $1,801.76 \mathrm{Ba}$ & $1,582.04 \mathrm{Aa}$ & $1,697.46 \mathrm{Ba}$ & $1,563.13 \mathrm{Aa}$ \\
MNC04-792F-148 & $453.45 \mathrm{Dc}$ & $551.58 \mathrm{Dc}$ & $1,238.74 \mathrm{Bb}$ & $1,882.33 \mathrm{Ba}$ & $1,307.83 \mathrm{Bb}$ \\
MNC04-795F-153 & $1,102.43 \mathrm{Cb}$ & $1,875.49 \mathrm{Ba}$ & $1,257.52 \mathrm{Bb}$ & $2,010.05 \mathrm{Ba}$ & $1,657.05 \mathrm{Aa}$ \\
MNC04-795F-154 & $1,730.27 \mathrm{Aa}$ & $1,398.56 \mathrm{Cb}$ & $1,730.78 \mathrm{Aa}$ & $1,760.80 \mathrm{Ba}$ & $1,218.85 \mathrm{Bb}$ \\
MNC04-795F-155 & $1,403.18 \mathrm{Bc}$ & $1,549.88 \mathrm{Cb}$ & $1,393.73 \mathrm{Ab}$ & $1,957.67 \mathrm{Ba}$ & $1,119.65 \mathrm{Bb}$ \\
MNC04-795F-159 & $589.92 \mathrm{Dc}$ & $1,431.94 \mathrm{Cb}$ & $1,389.03 \mathrm{Ab}$ & $2,316.20 \mathrm{Aa}$ & $1,178.97 \mathrm{Bb}$ \\
MNC04-795F-168 & $1,041.30 \mathrm{Cc}$ & $1,465.87 \mathrm{Cb}$ & $1,207.65 \mathrm{Bc}$ & $2,150.70 \mathrm{Aa}$ & $1,406.97 \mathrm{Ab}$ \\
BRS-Guariba & $1,646.55 \mathrm{Bb}$ & $2,126.14 \mathrm{Ba}$ & $1,301.24 \mathrm{Bc}$ & $1,762.00 \mathrm{Bb}$ & $1,390.62 \mathrm{Ac}$ \\
BRS-Tumucumaque & $2,021.17 \mathrm{Aa}$ & $1,332.92 \mathrm{Cb}$ & $1,309.78 \mathrm{Bb}$ & $1,924.30 \mathrm{Ba}$ & $1,426.68 \mathrm{Ab}$ \\
BRS-Novaera & $1,145.95 \mathrm{Cb}$ & $1,609.24 \mathrm{Ca}$ & $1,727.47 \mathrm{Aa}$ & $2,019.67 \mathrm{Ba}$ & $1,823.22 \mathrm{Aa}$ \\
BRS-Itaim & $941.13 \mathrm{Cb}$ & $1,623.50 \mathrm{Ca}$ & $1,192.32 \mathrm{Bb}$ & $1894.60 \mathrm{Ba}$ & $1,249.29 \mathrm{Bb}$ \\
BRS-Cauamé & $1096.16 \mathrm{Cc}$ & $1,489.89 \mathrm{Cb}$ & $973.03 \mathrm{Bc}$ & $1778.33 \mathrm{Ba}$ & $1,359.30 \mathrm{Ab}$ \\
\hline
\end{tabular}

Means followed by the same uppercase letter in the columns (comparing genotypes) and lowercase in the lines (comparing environments) do not differ by Scott-Knott test $(\mathrm{p}<0.05)$.

\section{CONCLUSIONS}

The cultivar BRS Nova Era and the lines MNC04-768F-21 and MNC04F-795F-168 had the highest bean yield in the environments evaluated in the State of Mato Grosso (Nova Ubiratã and Primavera do Leste) and also showed growth habit, plant lodging and cultivation value similar to those of the cultivar BRS-Guariba, which is widely cultivated in this region, and cultivar BRSTumucumaque, which is recommended for this state.

The cultivars BRS-Guariba, BRSTumucumaque, BRS-Novaera, BRS-Itaim and BRSCauamé and the lines MNC04-792F-143 and MNC04-792F-144 showed satisfactory bean yield and good growth habit, plant lodging and cultivation value in the environments of the State of Minas Gerais, especially in the state northern region (Jaíba and Janaúba), representing good alternatives for the genotypes recommended for this region.

\section{ACKNOWLEDGMENTS}

The authors thank the Brazilian Agricultural Research Corporation (Embrapa Mid-North), for providing the genotypes for this study; the Minas Gerais State Agency for Research and Development (Fapemig); the Brazilian National Council for Scientific and Technological Development (CNPq); and the Coordination for the Improvement of Higher Education Personnel (Capes) for the financial support and granting of scholarship.

\section{REFERENCES}

ARAÚJO, J. P. P.; WATT, E. E. O Caupi no Brasil. 1. ed. Brasília, DF: IITA/ EMBRAPA, 1988. 722 p.

BENVINDO, R. N. et al. Avaliação de genótipos de feijão-caupi de porte semiprostrado em cultivo de sequeiro e irrigado. Comunicata Scientiae, Teresina, v. 1, n. 1, p. 23-28, 2010.

BEZERRA, A. A. C. et al. Comportamento morfoagronômico de feijão-caupi, cv. BRS-Guariba, sob diferentes densidades de plantas. Revista de Ciências Agrárias, Recife, v. 55, n. 3, p. 184-189, 2012.

COCHRAN, W. G. The combination of estimates from different experiments. Biometrics, Washington, v. 10, n. 1, p. 101-129, 1954.

COMPANHIA

NASCIONAL

$\mathrm{DE}$ ABASTECIMENTO - CONAB. Acompanhamento da safra brasileira grãos. Disponível em: $<$ http:// www.conab.gov.br/OlalaCMS/uploads/ arquivos/16_08_09_12_08_19_boletim_graos_agost o_2016.pdf $\lesseqgtr$. Acesso em 01 ago. 2016.

CRUZ, C. D. Programa GENES: Biometria. 1. ed. Viçosa, MG: Editora UFV. 2006. 382 p.

EMPRESA BRASILEIRA DE PESQUISA AGROPECUÁRIA - EMBRAPA. Socioeconomia. Disponível em: <http://www.cnpaf.embrapa.br/ 
socioeconomia/index.htm>. Acesso em: 30 ago. 2016.

FOOD AND AGRICULTURE ORGANIZATION FAO FAOSTAT. Crops. Cow peas, dry. Disponível em: $\quad<$ http://faostat3.fao.org/home/ index.html\#DOWNLOAD>. Acesso em: 08 ago. 2016.

FREIRE FILHO, F. R. Feijão-Caupi no Brasil: Produção, melhoramento genético, avanços e desafios. 1. ed. Teresina, PI: EMBRAPA, 2011. 84 p.

FREIRE FILHO, F. R. et al. BRS-Novaera: cultivar de feijão-caupi de porte semi-ereto. Belém: Embrapa Amazônia Oriental, 2008. 4 p. (Comunicado Técnico, 215).

FREIRE FILHO, F. R. et al. Adaptabilidade e estabilidade produtiva de feijão-caupi. Ciência Rural, Santa Maria, v. 35, n. 1, p. 24-30, 2005.

INSTITUTO BRASILEIRO DE GEOGRAFIA E ESTATÍSTICA - IBGE. IBGE cidades. Disponível em: $\quad<$ http://cidades.ibge.gov.br/xtras/temas.php? lang $=\&$ codmun $=313510 \&$ idtema $=16 \&$ search $=\| \mathrm{s} \%$ EDntese-das-informa\%E7\%F5es:>. Acesso em: 05 ago. 2016.

MATOS FILHO, C. H. A. et al. Potencial produtivo de progênies de feijão-caupi com arquitetura ereta de planta. Ciência Rural, Santa Maria, v. 39, n. 2, p. 348-354, 2009.

MELO, F. B.; CARDOSO, M. J.; SALVIANO, A. A. C. Fertilidade do Solo e Adubação. In: FREIRE FILHO, F. R; LIMA, J.A de A; RIBEIRO, V. Q. (Eds.). Feijão-Caupi: avanços tecnológicos. Brasília, DF: Embrapa, 2005. cap. 6, p. 213-228.

NUNES, H. F. et al. Grain yield adaptability and stability of blackeyed cowpea genotypes under rainfed agriculture in Brazil. African Journal of Agricultural Research, Nairobi, v. 9, n. 2, p. 255 $261,2014$.

PEREIRA, H. S. et al. Influência do ambiente em cultivares de feijoeiro-comum em cerrado com baixa altitude, Bragantia, Campinas, v. 71, n. 2, p. 165 $172,2012$.

PIMENTEL-GOMES, F. P. Curso de estatística experimental. 15. ed. São Paulo, SP: FEALQ, 2009. $451 \mathrm{p}$.

ROCHA, M. M. et al. Adaptabilidade e estabilidade produtiva de genótipos de feijão-caupi de porte semiereto na Região Nordeste do Brasil. Pesquisa Agropecuária Brasileira, Brasília, v. 42, n. 9, p. 1283-1289, 2007.

ROCHA, M. M. et al. Seleção de genótipos de feijão-caupi tipo comercial Canapu no semiárido Piauiense. Teresina: Embrapa Meio-Norte, 2011. 33 p. (Embrapa Meio-Norte. Boletim de Pesquisa e Desenvolvimento, 99).

SANTOS, A. et al. Adaptabilidade e estabilidade de genótipos de feijão caupi ereto via REML/BLUP e GGE Biplot. Bragantia, Campinas, v. 75, n. 3, p. 299-303, 2016.

SANTOS, H. P. et al. Rendimento de grãos e características agronômicas de soja em função de sistemas de rotação de culturas. Bragantia, Campinas, v. 73, n. 3, p. 263-273, 2014.

SILVA, J. A. L.; NEVES, J. A. Componentes de produção e suas correlações em genótipos de feijãocaupi em cultivo de sequeiro e irrigado. Revista Ciência Agronômica, Fortaleza, v. 42, n. 3, p. 702 $713,2011$.

TEIXEIRA, N. J. P. et al. Produção, componentes de produção e suas inter-relações em genótipos de feijão -caupi [Vigna unguiculata (L.) Walp.] de Porte ereto. Revista Ceres, Viçosa, v. 54, n. 314, p. 374-382, 2007.

TEIXEIRA, N. J. P. et al. Desempenho agronômico e qualidade de sementes de cultivares de feijão-caupi na região do cerrado. Revista Ciência Agronômica, Fortaleza, v. 41, n. 2, p. 300-307, 2010.

VALADARES, R. N. et al. Adaptabilidade e estabilidade fenotípica em genótipos de feijão-caupi (Vigna unguiculata (L.) Walp.) de porte ereto/ semiereto nas mesorregiões leste e sul maranhense. Agropecuária Científica no Semiárido, Campina Grande, v. 7, n. 2, p. 21-27, 2012.

ZILIO, M. et al. Contribuição dos componentes de rendimento na produtividade de genótipos crioulos de feijão (Phaseolus vulgaris L.). Revista Ciência Agronômica, Fortaleza, v. 42, n. 2, p. 429-438, 2011 